\title{
Hervormde . Teologiese Studies
}

Jaargang 44

Aflewering 4

November 1988

Redakteur

Prof AG van Aarde

\section{Redaksie}

Proff JP Oberholzer (voorsitter), APB Breytenbach, TFJ Dreyer, BJ Engelbrecht, JJ Engelbrecht, JH Koekemoer, GMM Pelser, AD Pont, PJ van der Merwe, PM Venter en dr DJC van Wyk (sekretaris).

\section{Keuring}

Medewerkers se aandag word gevestig op die reëling dat bydraes formeel en inhoudelik deur die redaksie en ander vakkundiges gekeur word.

\section{Ortografiese vereistes}

Alle artikels, boek- en proefskrifbesprekings se ortografiese inrigting en literatuurverwysings moet voldoen aan die vereistes soos gepubliseer in Hervormde Teologiese Studies, Jaargang 42, Alfewering 1, Maart 1986, bl 195-206. Artikels moet aan die begin voorsien wees van ' $n$ taalversorgde Engelse ekserp wat naas ' $n$ vertaling van die titel, ' $n$ kort uiteensetting (hoogstens honderd woorde) van die bedoeling van die artikel bevat.

\section{Administrasie en intekening}

Mev Anne Barkhuizen, Tydskrifafdeling van die Nederduitsch Hervormde Kerk, Posbus 5777, 0001 Pretoria, Republiek van Suid-Afrika. Intekenprys R38 (studente R28), plus AVB, per jaargang met 4 aflewerings (Maart, Junie, September en November).

Gedruk deur Gutenberg Boekdrukkers

Uitgegee deur die Tydskrifafdeling van die Nederduitsch Hervormde Kerk van Afrika met die ondersteuning van die Universiteit van Pretoria en die Buro vir Wetenskaplike Publikasies by die Stigting vir Onderwys, Wetenskap en Tegnologie. Die redaksie, wat bestaan uit die lede van die Fakulteit Teologie (Afdeling A) van die

Universiteit van Pretoria, vereenselwig hom nie noodwendig met die menings deur medewerkers uitgespreek nie, kom alle normale redaksionele pligte na en voorbehou alle gebruiklike uitgewersregte. 


\section{LYS VAN MEDEWERKERS IN HIERDIE AFLEWERING}

Mnr Pieter JJ Botha, Departement Nuwe Testament, Universiteit van SuidAfrika, Posbus 392, 0001 Pretoria.

Prof dr JH Roberts, Departement Nuwe Testament, Universiteit van SuidAfrika, Posbus 392, 0001 Pretoria.

Prof dr AG van Aarde, Departement Nuwe-Testamentiese Wetenskap (Afd A), Universiteit van Pretoria, 0002 Pretoria.

Prof dr JWV van Huyssteen, Departement Bybelkunde, Universiteit van Port Elizabeth, 6000 Port Elizabeth.

Prof dr HF van Rooy, Departement Semitiese Tale, Potchefstroomse Universiteit vir CHO, 2520 Potchefstroom.

Dr Sjef van Tilborg, Burghard van den Bergstraat 109-111, 6512 DH Nijmegen, Nederland.

Ds DM van Zyl, Posbus 19240, 0117 Pretoria-Wes.

Prof dr WS Vorster, Instituut vir Teologiese Navorsing, Universiteit van Suid-Afrika, Posbus 392, 0001 Pretoria.

Ds APJ Beukes, Posbus 12264, 0014 Clubview.

Dr LC Bezuidenhout, Departement Semitiese Tale, Universiteit van Pretoria, 0002 Pretoria.

Prof dr CJ Botha, Departement Kerkgeskiedenis, Universiteit van Suid-Afrika, Posbus 392, 0001 Pretoria.

Prof dr TFJ Dreyer, Departement Praktiese Teologie (Afd A), Universiteit van Pretoria, 0002 Pretoria.

Dr JP Labuschagne, Posbus 225, 0300 Rustenburg.

Dr RM Naudé, Posbus 13599, 0129 Sinoville, Pretoria.

Dr DJ Smith, Posbus 16248, 0116 Pretoria-Noord.

Ds E van Eck, Posbus 28362, 0132 Sunnyside.

Dr DJC van Wyk, Departement Godsdiens- en Sendingwetenskap (Afd A), Universiteit van Pretoria, 0002 Pretoria.

Prof dr PM Venter, Departement Bybelkunde (Afd A), Universiteit van Pretoria, 0002 Pretoria. 